\title{
ASSESSMENT OF HEAVY METAL CONTAMINATION AND WATER QUALITY IN AN URBAN RIVER FROM ARGENTINA
}

\author{
MAGDALENO, A.*; DE CABO, L. ${ }^{1}$; ARREGHINI, S. ${ }^{2} \&$ SALINAS,.$^{3}$ \\ 1 - Museo Argentino de Ciencias Naturales "B. Rivadavia“ y Instituto National de Investigación de \\ Ciencias Naturales, Ángel Gallardo 470, C1405DJR, Buenos Aires, Argentina \\ 2 - Universidad de Buenos Aires, Av. San Martín 4453, C1417DSE, Buenos Aires, Argentina \\ 3 - Coordinación Ecológica Área Metropolitana Sociedad del Estado (CEAMSE), Av. Amancio Alcorta \\ 3000, 1437, Buenos Aires, Argentina \\ *Corresponding author: amagda65@yahoo.com.ar
}

\begin{abstract}
Magdaleno, A.; de Cabo, L.; Arreghini, S. \& Salinas, S. (2014) Assessment of heavy metal contamination and water quality in an urban river from Argentina. Braz. J. Aquat. Sci. Technol. 18(1): 113-120. elSSN 1983-9057. DOI: 10.14210/bjast.v18n1.p113-120 In aquatic ecosystems, the potential effects of toxic compounds are greatly determined by their physicochemical forms and bioavailability. The aim of this work was the assessment of metal toxicity to the green algae Pseudokirchneriella subcapitata in contaminated water samples of an urban river (Matanza-Riachuelo, Argentina). A total of 30 samples were analyzed. Physicochemical parameters and total and dissolved metal $(\mathrm{Cd}, \mathrm{Cu}, \mathrm{Cr}, \mathrm{Pb}, \mathrm{Ni}$ and $\mathrm{Zn}$ ) concentrations were measured. Toxicity was related as a function of size fractionation and chemical speciation (using the program Mineql+) in the dissolved fraction $(<1.2 \mu \mathrm{m})$. Percentage inhibition of algal growth (\%lw) was estimated as the differences between cultures with and without EDTA additions in the filtered water samples. Concentrations of $\mathrm{Cd}\left(1-85 \mu \mathrm{g} \cdot \mathrm{L}^{-1}\right), \mathrm{Cr}\left(3-164 \mu \mathrm{g} \cdot \mathrm{L}^{-1}\right)$, and $\mathrm{Ni}\left(10-99 \mu \mathrm{g} \cdot \mathrm{L}^{-1}\right)$ in river waters were always lower than the respective EC50 for $\mathrm{P}$. subcapitata, whereas concentrations of $\mathrm{Cu}\left(5-306 \mu \mathrm{g} \cdot \mathrm{L}^{-1}\right), \mathrm{Pb}\left(13-546 \mu \mathrm{g} \cdot \mathrm{L}^{-1}\right)$, and $\mathrm{Zn}\left(4-380 \mu \mathrm{g} \cdot \mathrm{L}^{-1}\right)$ in dissolved fractions resulted above the EC50 values in many samples. Only 10 samples showed algal growth inhibition (between $11.21 \%$ and $42.19 \%$ ), which 8 of them also showed high concentrations of free ionic forms of Pd or Zn. Free ionic concentrations of Cu were always lower than the EC50 for the algae. Two samples resulted toxic to $P$. subcapitata in spite of the absence of toxic metal concentrations. Besides, 13 samples no inhibited the algal growth and high concentrations of Pd and $\mathrm{Zn}$ were obtained, producing expected \%lw values between $10.03 \%$ and $90.51 \%$. The absence of toxicity in most samples with toxic metal concentrations could be related to the presence of organic ligands, colloidal organic matter, and antagonism effects among other metals, which reduce their bioavailability.
\end{abstract}

Keywords: Water pollution, toxicity test, Pseudokirchneriella subcapitata, heavy metals, Matanza-Riachuelo River

\section{INTRODUCTION}

Chemical pollution is one of the most critical threats to human populations and aquatic ecosystems. Many substances from industrial activities are released into natural waters without knowledge of the environmental potential risk. In complex aqueous environments, the chemical speciation of metals plays an important role in its bioavailability (Worms et al., 2006). According to the free ion activity model (FIAM), toxicity of metals on aquatic organisms is related to the free metal ion activity (Zeng et al. 2009). In this context, bioassays with microorganisms can be useful tools to evaluate the biological response to the potential toxicity of heavy metals in natural waters. Particularly, microalgae bioassays are excellent subjects for toxicity testing due to their easy maintenance and analysis conferred by their small size, large number and convenient growing conditions. The green alga Selenastrum capricornutum Printz, nowadays known as Pseudokirchneriella subcapitata is commonly used as a model organism of freshwater algae in standard toxicity tests (USEPA, 1989; Guéguen et al., 2004).
Heavy metal pollution in aquatic ecosystems constitutes a serious problem in Argentina due to the few environmental controls and political regulation of industrial discharges. This situation leads to regional deterioration of the water quality and aquatic ecosystems. Particularly, the Matanza-Riachuelo River (Buenos Aires, Argentina) is considered one of the most polluted rivers of Latin America (Blacksmith Institute, 2007). This temperate lowland river belongs to a densely populated basin of more 3.5 million inhabitants, and drains into the binational estuary Río de la Plata, which represents the main source of drinking water for Buenos Aires city and environs. Many metallurgic, chemical and petrochemical industries as well as meat processing plants and tanneries are located in the river banks, mainly in the lower basin. In addition, other sources of pollution as residential sewage waters, stormwater, and leachate from illegal solid waste dumps also contribute to pollution of the river waters (Magdaleno et al., 2008).

The aim of this work was to determine toxicity of heavy metals in water samples collected from 
the Matanza-Riachuelo River on the green alga $P$. subcapitata. Toxicity was related to the metal concentration in the filtered soluble fraction by adding ethylenediaminetetraacetic acid (EDTA) as a strong metal chelant. The algal growth inhibition was estimated at $96 \mathrm{~h}$ exposure as the differences between algal densities with and without EDTA additions. It was assumed that addition of EDTA to the filtered waters allows to complex the total free metals ions (Geis et al., 2000; Ma et al., 2003). Then, the bioavailability of metals diminished and also the toxicity of the whole water sample. Finally, the percentage inhibition of algal growth in river water was compared with the expected percentage inhibition for each free metal ion concentration calculated by chemical equilibrium modeling system and algal responses to pure metals in standard tests.

\section{MATERIALS AND METHODS}

\section{Sample collection}

Three sampling sites located along the main riverbed of the Matanza-Riachuelo River, Buenos Aires, Argentina (GPS: $34^{\circ} 37^{\prime} 54.8^{\prime \prime} \mathrm{S} 58^{\circ} 20^{\prime} 37.4^{\prime \prime} \mathrm{W}$ ) were chosen for the study (Figure 1). From upstream to downstream, the first site (S1) is located on the natural course of river, in an area with low urban concentration and few industrial activities, mainly metallurgic and meat processing plants. The second site (S2) is located on the first artificially straightened of river bed, in a scarcely populated area inside forest lands, where the water quality of river probably is partially recovered. The third site (S3) is located on the second straightened segment of river bed, in the highest urban and industrial concentration area. Industrial effluents from food, metallurgic, paper mill, chemical, petrochemical and tanning industries are discharged into the water, as well as municipal untreated wastewaters. Monthly samples were taken for 10 months.

Surface water samples were collected by triplicate into acid cleaned polypropylene bottles. For chemical measurements and algal bioassays, the samples were immediately filtered in the field with $1.2 \mu \mathrm{m}$ glass microfiber filters (Whatman grade GF/C), and kept in cold storage until laboratory analysis. For dissolved and total heavy metal determination, the filtered and non-filtered water was fixed immediately at $\mathrm{pH} 2$ with ultrapure $\mathrm{HNO}_{3}$, and stored in darkness at $4^{\circ} \mathrm{C}$ until analysis.

\section{Physicochemical measurements}

Water $\mathrm{pH}$, temperature and conductivity were measured in situ using adequate sensors (Hanna HI98129. HI98130). Dissolved oxygen (DO) was determined with the Winkler method, modified with sodium azide. Other chemical measurements were the follows: orthophosphate phosphorous $\left(\mathrm{PO}_{4}^{3-}\right.$ with molibdateascorbic acid), nitrate $\left(\mathrm{NO}_{3}^{-}\right.$by cadmium column reduction), nitrite $\left(\mathrm{NO}_{2}^{-}\right.$by diazotation), ammonium $\left(\mathrm{NH}_{4}{ }^{+}\right.$with indophenol blue), calcium and magnesium $\left(\mathrm{Ca}^{2+}\right.$ and $\mathrm{Mg}^{2+}$ by EDTA titration), sodium $\left(\mathrm{Na}^{+}\right.$with flame photometer), bicarbonate $\left(\mathrm{HCO}_{3}^{-}\right.$by heliantine titration), chloride ( $\mathrm{Cl}^{-}$by silver nitrate titration), and

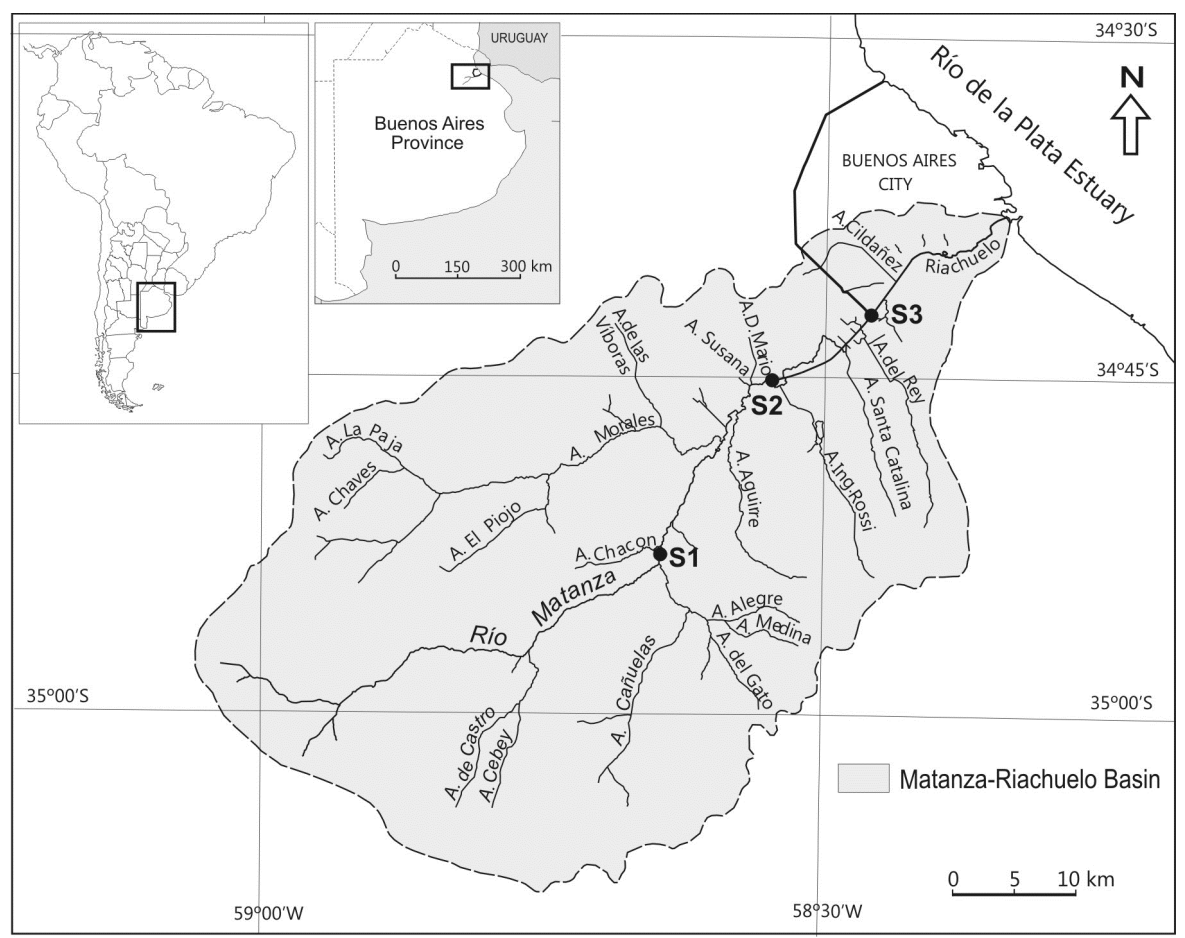

Figure 1 - Location of sampling sites in the Matanza-Riachuelo River (Buenos Aires, Argentina). 
sulphate $\left(\mathrm{SO}_{4}{ }^{2-}\right.$ by turbidimetry). The total suspended sediments (TSS) were determined gravimetrically using $1.2 \mu \mathrm{m}$ glass microfiber filters (Whatman grade GF/C). Particulate organic carbon (POC) and dissolved organic carbon (DOC) were measured by oxidization with sulphochromic solution at $100^{\circ} \mathrm{C}$. Samples for total and dissolved metal measurements (lead, zinc, cadmium, chromium, copper, nickel, manganese and iron) were concentrated and subjected to acid digestion. Then, metal concentrations were determined by atomic absorption spectrophotometry. All chemical analyses were carried on according to APHA (2012).

\section{Chemical speciation modeling}

As stated by the free-ion model, the real toxic agent is the free metal ion and not the metal complex (Zeng et al., 2009). The equilibrium concentrations of the metal species in water samples were calculated using the computer program (Schecher \& McAvoy, 1998). The present study analyzed the dissolved fractions of metals that were used in bioassays. Concentrations of $\mathrm{Ca}^{2+}, \mathrm{Mg}^{2+}, \mathrm{Na}^{+}, \mathrm{Cl}^{-}, \mathrm{SO}_{4}{ }^{2-}, \mathrm{HCO}_{3}{ }^{-}$and $\mathrm{pH}$ values were also introduced into the model.

\section{Bioassays in Algal Assay Medium}

Bioassays were performed using the green algae Pseudokirchneriella subcapitata (strain 278/4, from The Culture Collection of Algae and Protozoa). To analyze the toxic effect of metals on the algal growth, serial concentrations of $\mathrm{Pb}-\mathrm{Pb}\left(\mathrm{NO}_{3}\right)_{2}, \mathrm{Zn}-\mathrm{ZnSO}_{4} \cdot 7 \mathrm{H}_{2} \mathrm{O}$, $\mathrm{Cd}-\mathrm{CdCl}_{2}, \mathrm{Ni}-\mathrm{NiCl}_{2} \cdot 6 \mathrm{H}_{2} \mathrm{O}, \mathrm{Cu}-\mathrm{CuSO} \mathrm{S}_{4} \cdot 5 \mathrm{H}_{2} \mathrm{O}$ and $\mathrm{Cr}-$ $\mathrm{K}_{2} \mathrm{Cr}_{2} \mathrm{O}_{4}$ were tested separately using the Algal Assay Medium (AAM) prepared without EDTA (USEPA, 1989), that also was used as control and test dilutions. EDTA was not added, because its heavy metal chelant properties prevent assessment of heavy metal toxicity on algae. The initial inoculum cell density was $5 \pm 0.210^{4}$ cells $/ \mathrm{mL}$, and the assays were performed in triplicate using $125-\mathrm{mL}$ flasks containing $25 \mathrm{~mL}$ of medium. Cultures were incubated at $24^{\circ} \mathrm{C}$ in constant light $\left(23 \mu \mathrm{E} \cdot \mathrm{m}^{-2} \cdot \mathrm{s}^{-1}\right)$, and the algal growth was estimated by absorbance readings at $750 \mathrm{~nm}$ after $96 \mathrm{~h}$ incubation. The effective concentrations of metals inducing $50 \%$ effect (EC50) were calculated for each bioassay using the sigmoidal equation in the Origen Program (version 7.5). The percentage inhibition of the algal growth was plotted with respect to the control without metal (\%l) at each metal concentration. The effect for zero doses and the maximum effect were imposed in the model at 0 and 100 , respectively.

\section{Bioassays in river water samples}

Water samples from the Matanza-Riachuelo River were filtered and kept in cold storage to the laboratory. The bioassays were performed $24 \mathrm{~h}$ after sampling in two separated fractions of water: one fraction with $1 \mathrm{mg} / \mathrm{L} \mathrm{EDTA}$ addition, and the second fraction without EDTA. It was assumed that the addition of $1 \mathrm{mg} / \mathrm{L}$ EDTA to water samples allows to complex all the bioavailable metals (Greene et al., 1986). Then, the potential toxic effect on algal growth could be diminished comparing with those fractions without EDTA. No stock nutrient solution was added because of the high nutrient concentrations measured in the river waters. The bioassays were performed in triplicate using $125-\mathrm{mL}$ flasks containing $25 \mathrm{~mL}$ of water, and the algal initial density was $5 \pm 0.2 \times 10^{4} \mathrm{cells} / \mathrm{mL}$. The control of algal growth was carried out using the AAM medium. After $96 \mathrm{~h}$ incubation, the algal growth was estimated by absorbance readings at $750 \mathrm{~nm}$. Then, the percentage inhibition of algal growth in each water sample (\%lw) was calculated as:

$\% \mathrm{Iw}=(\mathrm{EW}-\mathrm{W}) / \mathrm{EW} \times 100$

where EW and W were the algal growth in the fractions with and without EDTA, respectively. It was taken into account those values which showed significant differences between $\mathrm{EW}$ and $\mathrm{W}$, with $p<0.05$. Then, the observed \%lw values from water samples were compared with the expected \%lw values calculated for free metal ion concentrations obtained by Mineql+ program (Schecher \& McAvoy, 1998), using the respective sigmoidal equations.

The chemical results obtained in the three sites were analyzed using a non-parametric statistical analysis - the Kruskal-Wallis test. This analysis was also used to evaluate significant differences in algal growth among treatments and sites. Pearson correlation coefficients were used to analyze the association between each free metal concentration and the observed \%lw values. Statistical tests were carried out using the software package STATISTICA ver. 5.0.

\section{RESULTS AND DISCUSSION}

\section{Physical and chemical parameters}

The average and standard deviation of physicochemical parameters in all the samples are presented in the Table 1. The nutrient water values are compared with the concentrations requirements of the algal growth medium AAM. The $\mathrm{pH}$ was similar for the three sites (7.2 - 7.6) and slightly higher than the algal culture medium, whereas the temperature mean values $\left(18^{\circ} \mathrm{C}\right.$ $-22^{\circ} \mathrm{C}$ ) were around the typical temperate river. The DO concentrations were near to the anoxic conditions at the sites S1 and S3 (1.5 and 0.4mg. $\mathrm{L}^{-1}$, respectively), and it was slightly higher than the minimum required for protection of aquatic life $\left(2.4 \mathrm{mg} . \mathrm{L}^{-1}\right)$ (DeZuane, $1997)$ at $S 2\left(5.4 \mathrm{mg} \cdot \mathrm{L}^{-1}\right)$. These low DO concentrations were due to the high inputs of organic matter (DOC 
Table 1 - Summary of river water analytical results (mean \pm standard deviation).

\begin{tabular}{|c|c|c|c|c|}
\hline \multirow[b]{2}{*}{ Parameter } & \multicolumn{3}{|c|}{ Sampling sites } & \multirow{2}{*}{$\begin{array}{c}\mathrm{AAM} \\
\text { medium }\end{array}$} \\
\hline & S1 & S2 & S3 & \\
\hline $\mathrm{pH}$ & $7.5 \pm 0.3$ & $7.6 \pm 0.5$ & $7.2 \pm 0.4$ & 7.0 \\
\hline Temperature $\left({ }^{\circ} \mathrm{C}\right)$ & $18.1 \pm 5.6$ & $20.7 \pm 6.3$ & $21.8 \pm 5.6$ & - \\
\hline Conductivity $\left(\mathrm{mS} . \mathrm{cm}^{-1}\right)$ & $1.9 \pm 0.5$ & $1.5 \pm 0.4$ & $1.8 \pm 0.6$ & - \\
\hline $\mathrm{DO}\left(\mathrm{mg} \cdot \mathrm{L}^{-1}\right)$ & $1.5 \pm 0.5$ & $5.4 \pm 2.1$ & $0.4 \pm 0.2$ & - \\
\hline $\mathrm{TSS}\left(\mathrm{mg} \cdot \mathrm{L}^{-1}\right)$ & $31.2 \pm 6.4$ & $42.0 \pm 0.5$ & $21.8 \pm 5.6$ & - \\
\hline $\mathrm{POC}\left(\mathrm{mg} \cdot \mathrm{L}^{-1}\right)$ & $19.5 \pm 17.5$ & $20.2 \pm 15.7$ & $23.5 \pm 15.9$ & - \\
\hline $\mathrm{DOC}\left(\mathrm{mg} \cdot \mathrm{L}^{-1}\right)$ & $202.2 \pm 76.3$ & $178.3 \pm 70.8$ & $199.3 \pm 76.9$ & 2.2 \\
\hline $\mathrm{NH}_{4}{ }^{+}\left(\mathrm{mg} \cdot \mathrm{L}^{-1}\right)$ & $12.3 \pm 6.7$ & $6.4 \pm 3.2$ & $12.9 \pm 5.5$ & - \\
\hline $\mathrm{NO}_{3}^{-}\left(\mathrm{mg} \cdot \mathrm{L}^{-1}\right)$ & $0.8 \pm 0.7$ & $1.1 \pm 0.9$ & $0.3 \pm 0.4$ & 8.4 \\
\hline $\mathrm{NO}_{2}^{-}\left(\mathrm{mg}^{-\mathrm{L}^{-1}}\right)$ & $0.3 \pm 0.2$ & $0.3 \pm 0.2$ & $0.2 \pm 0.5$ & - \\
\hline $\mathrm{PO}_{4}^{3-}\left(\mathrm{mg} \cdot \mathrm{L}^{-1}\right)$ & $2.8 \pm 1.2$ & $2.5 \pm 1.1$ & $2.6 \pm 0.9$ & 0.4 \\
\hline $\mathrm{Cl}^{-}\left(\mathrm{mg}^{-1} \mathrm{~L}^{-1}\right)$ & $206.5 \pm 50.8$ & $158.6 \pm 60.7$ & $340.5 \pm 28.5$ & - \\
\hline $\mathrm{SO}_{4}^{2-}\left(\mathrm{mg} \cdot \mathrm{L}^{-1}\right)$ & $121.3 \pm 57.3$ & $77.4 \pm 32.7$ & $89.5 \pm 37.6$ & 5.7 \\
\hline $\mathrm{Na}^{+}\left(\mathrm{mg}^{-1} \mathrm{~L}^{-1}\right)$ & $448.0 \pm 70.9$ & $281.0 \pm 37.7$ & $324.4 \pm 10.6$ & 11.0 \\
\hline $\mathrm{Mg}^{2+}\left(\mathrm{mg} \cdot \mathrm{L}^{-1}\right)$ & $27.0 \pm 6.1$ & $26.5 \pm 13.5$ & $32.8 \pm 19.1$ & 2.9 \\
\hline $\mathrm{Ca}^{2+}\left(\mathrm{mg}^{-\mathrm{L}^{-1}}\right)$ & $45.3 \pm 9.3$ & $41.5 \pm 5.9$ & $49.7 \pm 13.5$ & 1.2 \\
\hline $\mathrm{HCO}_{3}^{-}\left(\mathrm{mg}^{-1} \mathrm{~L}^{-1}\right)$ & $833.0 \pm 60.6$ & $667.9 \pm 65.5$ & $536.4 \pm 27.4$ & - \\
\hline Total Cd $\left(\mu \mathrm{g} \cdot \mathrm{L}^{-1}\right)$ & $40 \pm 36$ & $19 \pm 23$ & $22 \pm 28$ & - \\
\hline Dissolved Cd $\left(\mu \mathrm{g} \cdot \mathrm{L}^{-1}\right)$ & $26 \pm 27$ & $14 \pm 22$ & $12 \pm 27$ & - \\
\hline Total $\mathrm{Cr}\left(\mu \mathrm{g} \cdot \mathrm{L}^{-1}\right)$ & $26 \pm 75$ & $18 \pm 49$ & $6 \pm 18$ & - \\
\hline Dissolved $\mathrm{Cr}\left(\mu \mathrm{g} \cdot \mathrm{L}^{-1}\right)$ & $51 \pm 101$ & $28 \pm 61$ & $21 \pm 40$ & - \\
\hline Total $\mathrm{Cu}\left(\mu \mathrm{g} \cdot \mathrm{L}^{-1}\right)$ & $120 \pm 118$ & $106 \pm 94$ & $134 \pm 66$ & 1 \\
\hline Dissolved $\mathrm{Cu}\left(\mu \mathrm{g} \cdot \mathrm{L}^{-1}\right)$ & $96 \pm 116$ & $80 \pm 80$ & $100 \pm 70$ & 1 \\
\hline Total $\mathrm{Fe}\left(\mu \mathrm{g} \cdot \mathrm{L}^{-1}\right)$ & $3,040 \pm 0,850$ & $3,090 \pm 1,080$ & $2,890 \pm 0,334$ & 30 \\
\hline Dissolved $\mathrm{Fe}\left(\mu \mathrm{g} \cdot \mathrm{L}^{-1}\right)$ & $2,367 \pm 0,990$ & $2,610 \pm 1,170$ & $2,130 \pm 0,920$ & 30 \\
\hline Total Pb $\left(\mu \mathrm{g} \cdot \mathrm{L}^{-1}\right)$ & $148 \pm 180$ & $128 \pm 156$ & $213 \pm 202$ & - \\
\hline Dissolved $\mathrm{Pb}\left(\mu \mathrm{g} \cdot \mathrm{L}^{-1}\right)$ & $114 \pm 162$ & $119 \pm 158$ & $122 \pm 129$ & - \\
\hline Total $\mathrm{Mn}\left(\mu \mathrm{g} \cdot \mathrm{L}^{-1}\right)$ & $181 \pm 186$ & $140 \pm 109$ & $164 \pm 89$ & 110 \\
\hline Dissolved $\mathrm{Mn}\left(\mu \mathrm{g} \cdot \mathrm{L}^{-1}\right)$ & $141 \pm 163$ & $84 \pm 79$ & $144 \pm 85$ & 110 \\
\hline Total Ni $\left(\mu \mathrm{g} \cdot \mathrm{L}^{-1}\right)$ & $100 \pm 85$ & $65 \pm 59$ & $70 \pm 40$ & - \\
\hline Dissolved $\mathrm{Ni}\left(\mu \mathrm{g} \cdot \mathrm{L}^{-1}\right)$ & $58 \pm 62$ & $54 \pm 58$ & $46 \pm 35$ & - \\
\hline Total Zn $\left(\mu \mathrm{g} \cdot \mathrm{L}^{-1}\right)$ & $137 \pm 141$ & $97 \pm 94$ & $166 \pm 187$ & - \\
\hline Dissolved $Z n\left(\mu g \cdot L^{-1}\right)$ & $115 \pm 135$ & $79 \pm 83$ & $102 \pm 101$ & 1 \\
\hline
\end{tabular}

concentrations were between 178.3 and $202.2 \mathrm{mg} . \mathrm{L}^{-1}$ ), which consumes the oxygen in the water as it decays (Table 1). Likewise, the increases in $\mathrm{NH}_{4}{ }^{+}$concentrations (between 6.4 and $12.9 \mathrm{mg}^{\mathrm{L}} \mathrm{L}^{-1}$ ), accompanied by lower $\mathrm{NO}_{3}^{-}$(from 0.3 to $1.1 \mathrm{mg}^{-\mathrm{L}^{-1}}$ ) and $\mathrm{NO}_{2}^{-}(0.2$ and $0.3 \mathrm{mg}^{-\mathrm{L}^{-1}}$ ) values, also suggest a recent organic contamination. The maximum values of $\mathrm{NH}_{4}{ }^{+}$and $\mathrm{NO}_{2}{ }^{-}$ allowed for the aquatic life protection by Argentine law are 1.3 and $1.0 \mathrm{mg} . \mathrm{L}^{-1}$, respectively. Therefore, ammonium concentrations exceeded more than five times that value. The DOC concentrations in waters exceeded two orders of magnitude the requirements of the algal culture, whereas the ammonium represented almost the main source of inorganic nitrogen, being the nitrate the suitable form incorporated by algae (Table 1). In general, the concentrations of nutrients in the river water were higher than in the algal medium.

The water quality of the Matanza-Riachuelo River was similar at the three sites, and slightly better at S2 due to the simultaneous occurrence of higher DO concentration and lower concentrations of $\mathrm{NH}_{4}^{+}, \mathrm{Cl}^{-}$, $\mathrm{SO}_{4}{ }^{2-}$ and DOC than at the others two sites. Significant differences were observed among the three sites in the parameters $\mathrm{DO}, \mathrm{NO}_{2}^{-}, \mathrm{NH}_{4}^{+}, \mathrm{Cl}^{-}$and $\mathrm{SO}_{4}{ }^{2-}(p<$ $0.05)$, according to the Kruskal-Wallis test. Elevated levels of dissolved metals were measured (Table 1), exceeding the USEPA guideline for the protection of aquatic life $\left(\mathrm{Cu}=2.33 \mu \mathrm{g} \cdot \mathrm{L}^{-1}, \mathrm{Cd}=2 \mu \mathrm{g} \cdot \mathrm{L}^{-1}, \mathrm{Cr} \mathrm{VI}=16 \mu \mathrm{g} \cdot \mathrm{L}^{-1}\right.$, $\mathrm{Pb}=65 \mu \mathrm{g} \cdot \mathrm{L}^{-1}, \mathrm{Ni}=52 \mu \mathrm{g} \cdot \mathrm{L}^{-1}$, and $\mathrm{Zn}=120 \mu \mathrm{g} \cdot \mathrm{L}^{-1}$ ) (USEPA, 2009). Dissolved metal fraction in waters was between $60 \%$ and $80 \%$ of the total metal fraction. The major contributors to water pollution in S1 and S3 are industrial facilities (chemical and metallurgic manufacturing, tanneries and food processing), sewage and urban waste-water scattered in the region. However, similar conditions of water pollution were detected at S2, located inside a forest and undeveloped area.

\section{Bioassays}

The percentage inhibition of algal growth (\%l) versus each individual ionic metal concentration were plotted to obtain the sigmoidal equation (Figure 2). The EC50 were calculated from the respective sigmoidal equation of each metal, in conditions of EDTA-free standard culture medium, with $95 \%$ of confidence interval (Table 2). According to these values, $\mathrm{Cu}, \mathrm{Zn}$ and Cd were the most toxic metals (EC50 $=90,100$ and $120 \mu \mathrm{g} . \mathrm{L}^{-1}$, respectively), whereas $\mathrm{Ni}, \mathrm{Cr}$ and $\mathrm{Pb}$ were less toxic $\left(E C 50=150,210\right.$ and $350 \mu \mathrm{g} \cdot \mathrm{L}^{-1}$, respectively). These concentrations were similar than those proposed by Blaise et al. (1998), Geis et al. (2000) and Guéguen et al. (2004) for $P$. subcapitata.

The algal growth in river water was not significantly different between S2 and S3, according to the 
Kruskal-Wallis test, showing similar abiotic conditions in these sites (Figure 3). However, significant differences with respect to S1 were observed in several months $(p<0.05)$. The lower cell density after $96 \mathrm{~h}$ incubation was obtained in the warm months of the year, between November and January (between 0.9 - $2.9 x$ $10^{6}$ cells $/ \mathrm{mL}$ ), and the higher growth was reached in September, March and April (3.9-6.7 × $10^{6}$ cells. $\mathrm{mL}^{-1}$ ). On the other hand, the control in AAM medium was maintained between 3.5 and $4.0 \times 10^{6} \mathrm{cells} / \mathrm{mL}$, after $96 \mathrm{~h}$ of growth. Considering that nutrient concentrations in river waters were higher than the requirements of algae (Table 1), it was expected higher growth in the samples than in the control. However, the algal growth in river waters was significantly lower than the obtained
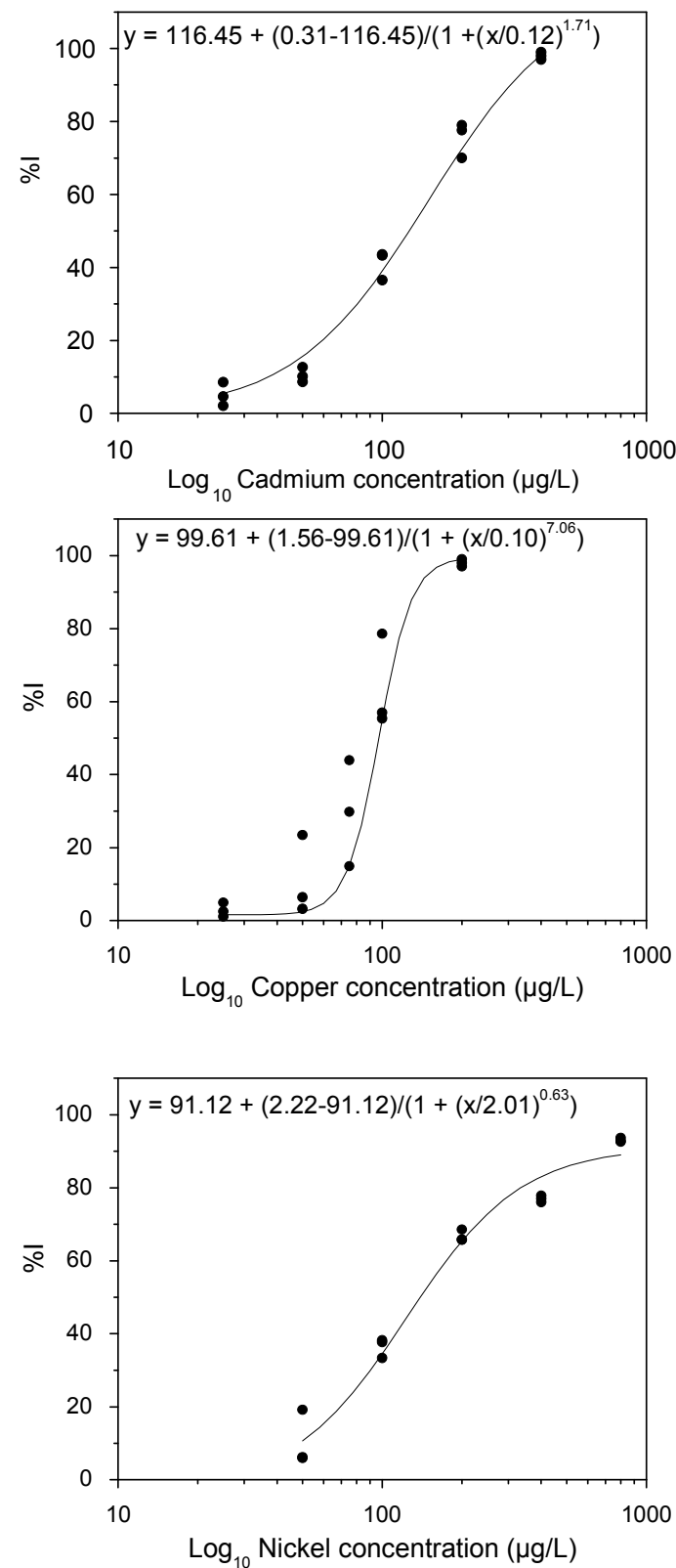

in AAM medium in several samples $(p<0.05)$ (using the Kruskal-Wallis test): S1, S2 and S3 in November, December, January and July; S2 in June, August and October; S3 July and August. Besides, significant differences between river waters with and without EDTA additions were observed $(p<0.05)$ : S1 (September, November, December, January and June), S2 (August and October), and S3 (September, November and December).

Concentrations of $\mathrm{Cd}\left(1-85 \mu \mathrm{g} \cdot \mathrm{L}^{-1}\right), \mathrm{Cr}(3-$ $\left.164 \mu \mathrm{g} \cdot \mathrm{L}^{-1}\right)$, and $\mathrm{Ni}\left(10-99 \mu \mathrm{g} \cdot \mathrm{L}^{-1}\right)$ in the dissolved tested fraction of waters were always lower than the respective EC50 for $P$. subcapitata, whereas $\mathrm{Cu}(5$ $\left.306 \mu \mathrm{g} . \mathrm{L}^{-1}\right), \mathrm{Pb}\left(13-546 \mu \mathrm{g} \cdot \mathrm{L}^{-1}\right)$, and $\mathrm{Zn}\left(4-380 \mu \mathrm{g} \cdot \mathrm{L}^{-1}\right)$ were higher than the respective EC50 in several sam-
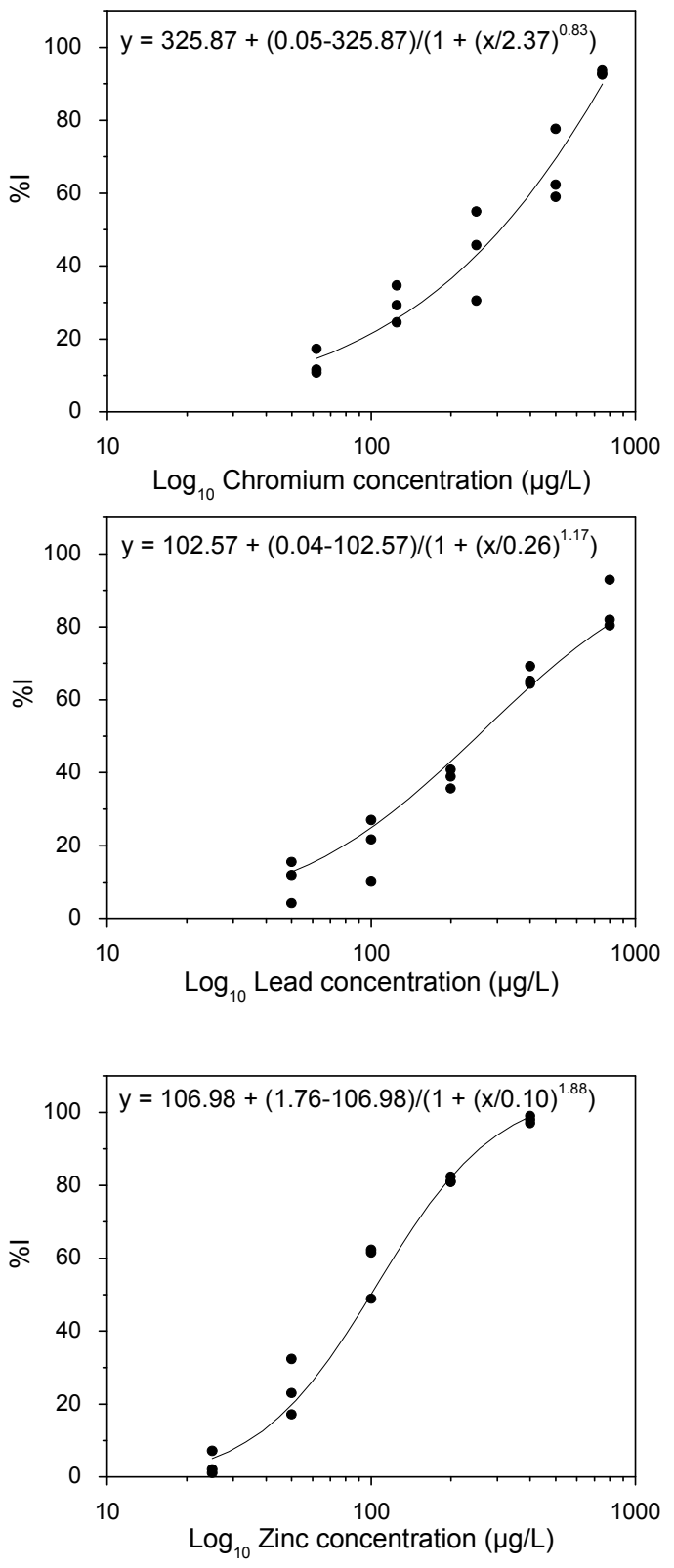

Figure 2 - Inhibition percentage (\%l) of the algal growth by metal concentrations with respect to the control in AAM medium without EDTA. It was plotted the sigmoidal curve for each metal from three independent assayed results. 
Table 2 - EC50 values obtained by the sigmoidal equation to each metal.

\begin{tabular}{lll}
\hline \hline Metal $\left(\mu g \cdot \mathrm{L}^{-1}\right)$ & EC50 $(95 \% \mathrm{Cl})$ & Ref. value \\
\hline Cadmium & $120(90-170)$ & $10-130^{\mathrm{a}, \mathrm{b}}$ \\
Chromium $(\mathrm{VI})$ & $210(190-280)$ & $40-900^{\mathrm{a}}$ \\
Copper & $90(80-100)$ & $20-940^{\mathrm{a}}$ \\
Lead & $350(260-590)$ & $290-2700^{\mathrm{a}}$ \\
Nickel & $150(130-180)$ & $300^{\mathrm{c}}$ \\
Zinc & $100(80-130)$ & $50-310^{\mathrm{a}, \mathrm{b}}$ \\
\hline
\end{tabular}

Reference values with $P$. subcapitata by (a) Guéguen et al. (2004); (b) Blaise et al. (1998) and (c) Geis et al. (2000).

ples of the three river sites. Therefore, copper, lead and zinc would contribute to the toxicity. However, the measured concentration of metal in the dissolved fraction is not a reliable indicator of toxicity. In natural water systems, trace metals can be partitioned between different physical states such as free or complexed, associated with colloids or with particles. It is often assumed that the bioavailability of metals depends on the free ionic and labile form for microorganisms (Zhou et al., 2008). The free metal concentrations of $\mathrm{Cu}, \mathrm{Pb}$ and $\mathrm{Zn}$ in water samples from the MatanzaRiachuelo River using the computer program Mineql+ are shown in Table 3. The free ionic forms of copper and lead were below the respective EC50 estimated for $P$. subcapitata in all cases. According to $\mathrm{pH}$ values, copper was mainly complexed with malachite and tenorite in many samples. Besides, free copper ions may gradually decrease with increasing the concentrations of carbonates and calcium (Fathi et al., 2012). On the other hand, zinc was slightly bound by chelators with more than $60 \%$ remaining as free ion. Eleven samples showed free zinc ionic concentrations above the EC50 value (Table 2 and 3 ).

Taken into account the free ion concentrations of $\mathrm{Cu}, \mathrm{Pb}$ and $\mathrm{Zn}$, we calculated the expected \%lw values to each metal using the respective sigmoidal equation. These values were compared with the obtained \%lw in all the samples (Table 4). We considered as no toxic the expected \%lw values lower than $10 \%$. Ten of the total 30 analyzed samples were toxic to $P$. subcapitata, obtaining \%lw values between $11.21 \%$ and $42.19 \%$. According to the free metal ion concentrations, toxicity was mainly explained by zinc and lead, whereas copper concentrations were maintained lower than the EC50 value for $P$. subcapitata (Table 2). However, no correlation between free metal concentrations and toxicity was observed, according to the Pearson correlation analysis $(p<0.05)$. Eight samples showed algal growth inhibition in agreement with high $\mathrm{Zn}$ and $\mathrm{Pb}$ concentrations, mainly between September and January, but the expected \%lw values by Zn were higher that the observed \%lw. On the contrary, two samples were also toxic to the algae in spite of no detectable concentrations of dissolved $\mathrm{Zn}$. On the other hand, 13 samples were no toxic to the algae, but expected \%lw values (between $10.03 \%$ and $90.51 \%$ ) by high levels of

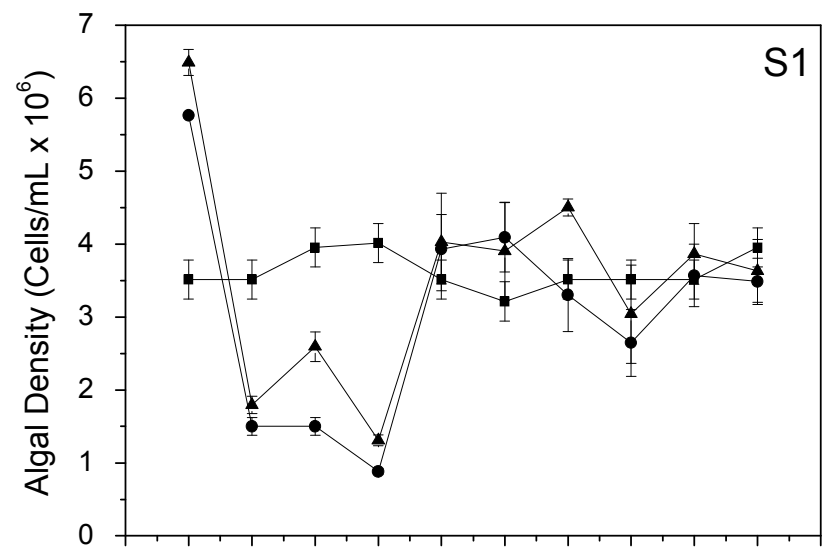

Sep Nov Dec Jan Mar Apr Jun Jul Aug Oct

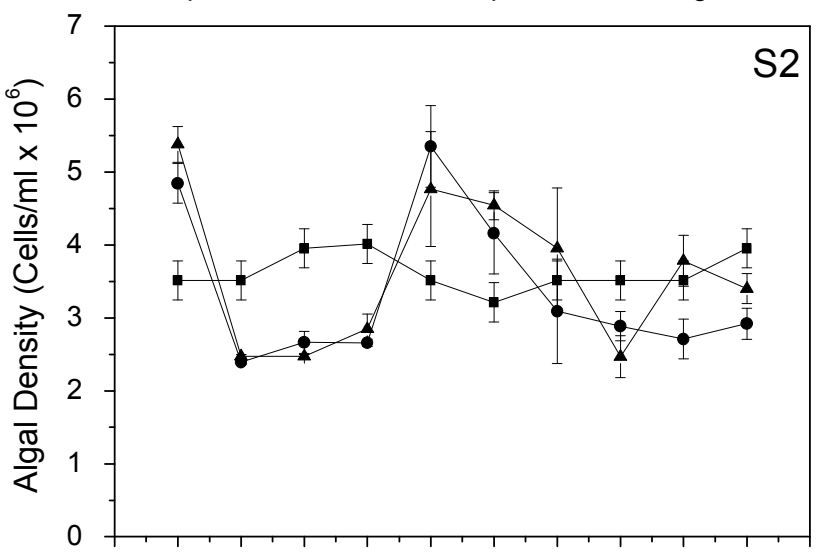

Sep Nov Dec Jan Mar Apr Jun Jul Aug Oct

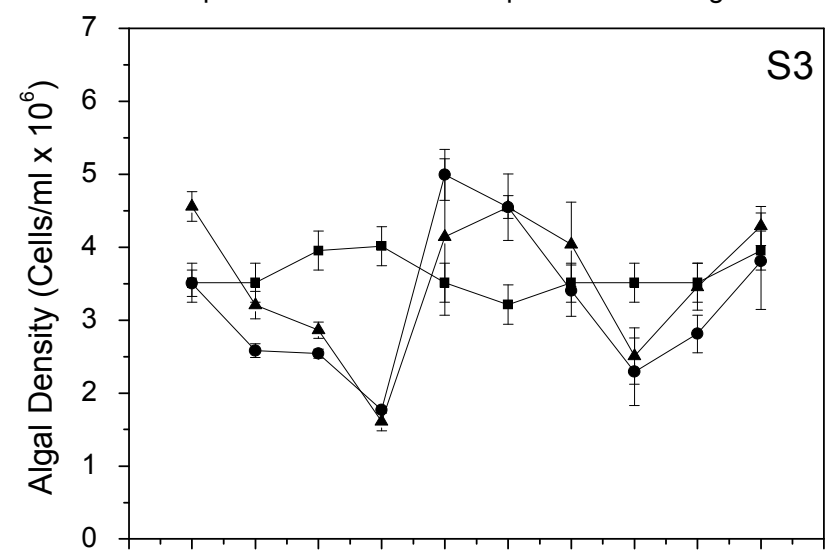

Sep Nov Dec Jan Mar Apr Jun Jul Aug Oct

Figure 3 - Algal growth in the river water $(\bullet)$ and the river water with EDTA additions $(\boldsymbol{\Delta})$ at each month of sampling and the three sites. The control was carried on using the AAM medium ( $\mathbf{})$.

$\mathrm{Zn}$ or $\mathrm{Pb}$ and potential toxic concentrations of $\mathrm{Zn}$ were obtained, mainly in the samples from March and April (Table 4). However, six samples were also no toxic to $P$. subcapitata, and no toxic metal concentrations were calculated by Mineql+ program.

Four situations were observed: 1) toxicity occurrence in agreement with toxic levels of metals, 2) no toxicity in agreement with low or no detectable metal concentrations, 3) no toxicity in spite of poten- 
Table 4 - Percentages of algal growth inhibition measured in river water samples (Obs. \%lw), and the expected values (Exp. \%lw) obtained from the sigmoidal equation to each metal ion concentration (calculated by Mineql+).

\begin{tabular}{|c|c|c|c|c|c|c|c|c|c|c|c|c|}
\hline & \multicolumn{4}{|c|}{$\overline{\mathrm{S} 1}$} & \multicolumn{4}{|c|}{$\overline{S 2}$} & \multicolumn{4}{|c|}{$\overline{\text { S3 }}$} \\
\hline & Obs.\%lw & $\begin{array}{l}\text { Exp. \%lw } \\
\text { by } \mathrm{Cu}^{2+}\end{array}$ & $\begin{array}{l}\text { Exp. \%lw } \\
\text { by } \mathrm{Pb}^{2+}\end{array}$ & $\begin{array}{l}\text { Exp. \%lw } \\
\text { by } \mathrm{Zn}^{2+}\end{array}$ & Obs. \%lw & $\begin{array}{l}\text { Exp. \%lw } \\
\text { by } \mathrm{Cu}^{2+}\end{array}$ & $\begin{array}{l}\text { Exp. \%lw } \\
\text { by } \mathrm{Pb}^{2+}\end{array}$ & $\begin{array}{l}\text { Exp. } \% / w \\
\text { by } \mathrm{Zn}^{2+}\end{array}$ & Obs. \%lw & $\begin{array}{l}\text { Exp. \%lw } \\
\text { by } \mathrm{Cu}^{2+}\end{array}$ & $\begin{array}{l}\text { Exp. \%lw } \\
\text { by } \mathrm{Pb}^{2+}\end{array}$ & $\begin{array}{c}\text { Exp. \%lw } \\
\text { by } \mathrm{Zn}^{2+}\end{array}$ \\
\hline September & 11.21 & - & n.t. & 45.82 & n.t. & - & n.t. & 33.50 & 23.10 & - & n.t. & 26.90 \\
\hline November & 16.59 & n.t. & n.t. & 86.52 & n.t. & n.t. & n.t. & 63.29 & 19.40 & n.t. & 18.46 & 69.83 \\
\hline December & 42.19 & n.t. & n.t. & 77.21 & n.t. & n.t. & n.t. & 13.99 & 11.26 & n.t. & 17.96 & 58.62 \\
\hline January & 32.65 & n.t. & n.t. & 95.40 & n.t. & n.t. & n.t. & 82.75 & n.t. & n.t. & n.t. & 84.33 \\
\hline March & n.t. & n.t. & 37.63 & 78.86 & n.t. & n.t. & 30.19 & 79.74 & n.t. & n.t. & 44.65 & 90.51 \\
\hline April & n.t. & n.t. & 26.40 & 15.20 & n.t. & n.t. & 23.49 & 25.57 & n.t. & - & - & - \\
\hline June & 27.24 & n.t. & n.t. & n.t. & n.t. & n.t. & n.t. & n.t. & n.t. & n.t. & n.t. & 10.03 \\
\hline July & n.t. & n.t. & n.t. & n.t. & n.t. & n.t. & n.t. & 12.81 & n.t. & n.t. & n.t. & 36.09 \\
\hline August & n.t. & n.t. & n.t. & n.t. & 28.44 & n.t. & n.t. & n.t. & n.t. & n.t. & n.t. & n.t. \\
\hline October & n.t. & n.t. & n.t. & n.t. & 14.19 & n.t. & n.t. & 20.93 & n.t. & n.t. & n.t. & n.t. \\
\hline
\end{tabular}

tial levels of metals, and 4) toxicity occurrence but no toxic levels of metals. The first situation could mainly be related to the presence of zinc concentrations. However, the expected \%l values (calculated from the standard sigmoidal equation) were significantly higher than the observed ones, most probably due to the complexes forms of $\mathrm{Zn}$ with EDTA in the bottle test, or also by the presence of other organic ligand in river waters. Nevertheless, the obtained \%lw suggest that ligand concentrations were not sufficient to complex metal and prevent toxicity. According to Guéguen et al. (2004), the weak toxicity to P. subcapitata in dissolved river waters with high concentrations of $\mathrm{Zn}$ was be explained by high concentrations of phenol as a strong metal ligand. These authors discuss that thermodynamic stability constants for phenol in the Mineql+ model are not available, thus the calculated free metal ion concentrations could be overestimated. Likewise, precipitated forms of copper-induced toxicity could be occurred during bioassays.

The third situation (no toxicity and potential toxic metal concentrations) could be also explained by the previous explanation. Besides, sorption of colloidal organic matter to the algal cell surface protecting them from pollutants in waters might be also occurred (Koukal et al., 2003; McIntyre and Guéguen, 2013). The high levels of DOC (Table 1) could indicate the presence of natural organic ligands, as the humic acids, forming complex with the ionic forms of metals, and also reducing their bioavailability for algae. This could be support by Rendina et al. (2001) who showed that lead and copper are mainly bounded to the organic matter and sulfides fractions in sediments of this river. On the other hand, some of these samples showed simultaneously toxic concentrations of $\mathrm{Pb}$ and $\mathrm{Zn}$. It was demonstrated that toxic metals may compete for the cellular binding sites in some concentrations, establishing antagonistic interactions. Binary mixtures of $\mathrm{Pb}$ and $\mathrm{Zn}$ showed antagonistic effect on algae (Chen et al. 1997).
The fourth situation only occurred in two samples (toxicity and the absence of toxic metal concentrations). Errecalde et al. (1998) have shown that toxicity of divalent cations $\left(\mathrm{Zn}^{2+}\right.$ and $\left.\mathrm{Cd}^{2+}\right)$ is enhanced in the presence of citrate in Selenastrum capricornutum. We not discard citrate presence and/or high levels of other metal not considered in this study producing the algal growth inhibition.

\section{CONCLUSION}

Toxicity by free metal concentrations in $P$. subcapitata was only explained in 8 of the total 30 samples, mainly by $\mathrm{Zn}$. Copper was not contribute to the algal inhibition growth. Standard laboratory bioassays demonstrated that metal concentrations potentially harmful for algae in culture medium do not reflect the toxic effects induced by exposure to contaminated water samples. The algal growth inhibition was generally much lower than could be predicted, according to their individual EC50, and no toxicity was observed in samples with high or potential toxic concentrations of $\mathrm{Zn}$ or $\mathrm{Pb}$ and $\mathrm{Zn}$. According to the numerous industries located around the MatanzaRiachuelo River, the organic pollution is also important and could interact with metals determining the presence or absence of toxic effects. Measurement of organic contaminants deserves to be considered in further monitoring studies in this river.

Given the extreme complexity of toxic effects in pollutant mixtures, contributions of individual chemicals to the total toxicity should not be quantified before a very complete set of experiments are performed to assess pollutants interactions. Two factors could be taken into account to further monitoring studies on the Matanza-Riachuelo: (1) the analysis of organic pollutants in waters and their interaction with metals, and (2) the protective role of colloids reducing metal toxicity in algae. 


\section{ACKNOWLEDGEMENTS}

This work was supported by grants from the Agencia Nacional de Promoción Científica y Tecnológica (ANPCyT), PICT Nº0-356. The authors want to thank Mrs. Amalia González for the artwork.

\section{REFERENCES}

American Public Health Association (APHA), American Water Works Association (AWWA), Water Pollution Control Federation (WPCF). 2012. Standard Methods for the Examination of Water and Wastewater. 22nd ed. Washington: American Public Health Association, 1360 pp.

Blacksmith Institute. 2007. The world's worst polluted places. The top ten of the dirty thirty. Final Report. http://www.blacksmithinstitute.org

Blaise, C.; Férard, J.F. \& Vasseur, P. 1998. Microplate toxicity tests with microalgae: a review. In: Wells, P.; Lee, K. \& Blaise, C. (eds). Microscale Testing in Aquatic Toxicology. Advances, Techniques and Practice. CRC Boca Raton. 269-288 pp.

Chen, C.Y.; Lin, K.C. \& Yang, D.T. 1997. Comparison of the relative toxicity relationships based on batch and continuous algal toxicity tests. Chemosphere. 35: 1959-1965.

DeZuane, P.E.J. 1997. General or physical parameters. In: DeZuane, P.E.J. (ed). Handbook of Drinking Water Quality. Van Nostrand Reinhold, New York. 19-47 pp.

Errécalde, O.; Seidl, M. \& Campbell, P.G.C. 1998. Influence of a low molecular weight metabolite (citrate) on the toxicity of cadmium and zinc to the unicellular green alga Selenastrum capricornutum: an exception to the free-ion model. Wat. Res. 321: 419-429.

Fathi, A.A.; Azooz, M.M. \& Al-Fredan, M.A. 2012. Abolishing toxicity of copper by some environmental factors using green alga Chlorella vulgaris. American Journal of Environmental Science. 8 (6): 633- 641.

Geis, S.W.; Fleming, K.L.; Korthals, E.T.; Searle, G.; Reynolds, L. \& Karner, D.A. 2000. Modifications to the algal growth inhibition test for use as a regulatory assay. Environ. Toxicol. Chem. 19: 36-41.

Greene, J.C.; Miller, W.E. \& Merwin, E. 1986. The effect of secondary effluents on eutrophication in Las Vegas Bay, Lake Mead, Nevada. Water, Air, Soil Pollut. 29: 391-402.

Guéguen, C.; Gilbin, R.; Pardos, M. \& Dominik, J. 2004. Water toxicity and metal contamination assessment of a polluted river: the Upper Vistula River (Poland). Appl. Geochem. 19: 153-162.
Koukal, B.; Guéguen, C.; Pards, M. \& Dominik, J. 2003. Influence of humic substances on the toxic effects of cadmium and zinc to the green alga Pseudokirchneriella subcapitata. Chemosphere. 53: 953-961.

Ma, M.; Zhu, W.; Wang, Z. \& Witkamp, G.J. 2003. Accumulation, assimilation and growth inhibition of copper on freshwater alga (Scenedesmus suspicatus $86.81 \mathrm{SAG}$ ) in the presence of EDTA and fulvic acid. Aquat. Toxicol. 63: 221-228.

Magdaleno, A.; Mendelson, A.; Fabrizio de lorio, A.; Rendina, A. \& Moretton, J. 2008. Genotoxicity of leachates from highly polluted lowland river sediments destined for disposal in landfill. Waste Manag. 28: 2134-2139.

Mclntyre, A.M. \& Guéguen, C. 2013. Binding interactions of algal-derived dissolved organic matter with metal ions. Chemosphere. 90: 620-626.

Rendina, A.; Bargiela, M.; de Cabo, L.; Arreghini, S. \& Fabrizio de lorio. A. 2001. Formas geoquímicas de metales pesados en sedimentos del Río Matanza y principales afluentes. Rev. Mus. Argentino Cienc. Nat. 3: 33-39.

Schecher, W. \& McAvoy, D.C. 1998. MINEQL+: A chemical equilibrium modeling system. Version 4.0 for Windows, Environmental Research Software, Hallowell, Marine.

U.S. Environmental Protection Agency. 1989. Algal (Selenastrum capricornutum) growth test. Shortterm methods for estimating the chronic toxicity of effluents and receiving waters to freshwater organisms. Environmental Monitoring System Laboratory, Environmental Protection Agency. $147 \mathrm{p}$.

U.S. Environmental Protection Agency. 2009. National Recommended Water Quality Crieteria. 4304T. http://www.epa.gov/ost/criteria/wqctable.

Worms, I.; Simon, D.F.; Hassler, C.S. \& Wilkinson, K.J. 2006. Bioavailability of trace metals to aquatic microorganisms: importance of chemical, biological and physical processes on biouptake. Biochimie. 88: 1721-1731.

Zeng, J.; Yang, L.Y. \& Wang, W.X. 2009. Cadmium and zinc uptakeand toxicity in two strains of Microcystis aeruginosa predicted by metal free ion activity and intracellular concentration. Aquatic Toxicology. 91: 212-220.

Zhou Q, Zhang J, Fu J, Shi J, Jiang G. 2008. Review. Biomonitoring: An appealing tool for assessment of metal pollution in the aquatic ecosystem. Anal Chim Acta 606:135-150. doi:10.1016/j.aca.2007.11.018

Submetido: Outubro/2012 Revisado: Fevereiro/2014 Aceito: Março/2014 